\title{
Dyp hjernestimulering ved essensiell tremor
}

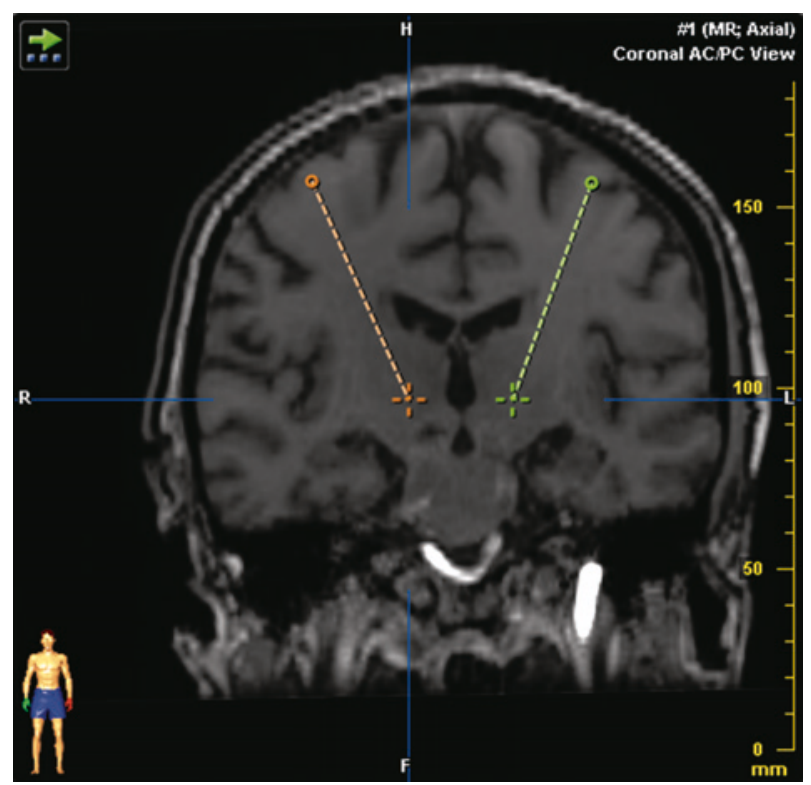

En mann i 70-årsalderen hadde helt fra ungdomsårene utviklet essensiell tremor i hender og underarmer og etter flere år også hodetremor, som ja-bevegelse. Tilstanden hadde progrediert over tid. I løpet av de siste årene var det blitt en forverring, med økt tremoramplitude. Han hadde ikke hatt nevneverdig nytte av medikamenter som propranolol, primidon eller gabapentin, heller ikke av injeksjoner med botulinumtoksin. Tilstanden innebar et betydelig handikap - han hadde problemer med å føre en kopp til munnen og vansker med spising og påkledning. Han ble henvist med tanke på dyp hjernestimulering.

Videoen viser uttalt postural tremor når høyre overekstremitet holdes ut fra kroppen, og kinetisk tremor, særlig i form av intensjonstremor ved slutten av finger-nese-prøve på høyre side. Illustrasjonen, et T1-vektet MR-bilde i koronalt plan, viser planlagt plassering av elektroder til Vim-kjernen (nucleus ventrointermedius). Venstre og høyre elektrode er visualisert $\mathrm{i}$ henholdsvis grønt og oransje. Implantasjon av elektrodene bilateralt i Vim-kjernen ga tydelig bedring hos pasienten. Det var full tremorsuppresjon, noe som ses i andre del av videoen.

Essensiell tremor er vanlig $(0,4-3,9 \%)$, men trolig underdiagnostisert $\mathrm{i}$ befolkningen (1). Thalamusstimulering er aktuelt hvis pasienten har en sterkt invalidiserende tremor som ikke har respondert tilfredsstillende på medikamentell behandling. Ved dyp hjernestimulering ved essensiell tremor legges det inn elektroder i Vim-kjernen i thalamus, og høyfrekvent elektrisk strøm leveres ved hjelp av en pulsgenerator som implanteres sub- kutant på thorax. Metoden ble tatt i bruk ved Rikshospitalet i 1996, og årlig opereres 12-14 pasienter her på denne indikasjonen. Impulsgeneratoren kan skrus av og på, og strømfeltets styrke og eksakte lokalisering kan endres via ekstern programmering (2).

Pasienten har gitt samtykke til at artikkelen blir publisert.

\section{Mirza Jusufovic}

mirzajus@hotmail.com

Nevrologisk avdeling

Klinikk for kirurgi og nevrofag

\section{Ane Eidahl Konglund}

Nevrokirurgisk avdeling

Klinikk for kirurgi og nevrofag

\section{Mona Kristiansen Beyer}

Enhet for nevroradiologi

Klinikk for diagnostikk og intervensjon

\section{Espen Dietrichs}

Nevrologisk avdeling

Klinikk for kirurgi og nevrofag

\section{Mona Skjelland}

Nevrologisk avdeling

Klinikk for kirurgi og nevrofag

Oslo universitetssykehus, Rikshospitalet

Mirza Jusufovic (f. 1980) er assistentlege i nevrologi.

Forfatter har fylt ut ICMJE-skjemaet og oppgir ingen interessekonflikter.

Ane Eidahl Konglund (f. 1978) er spesialist i nevrokirurgi.

Forfatter har fylt ut ICMJE-skjemaet og oppgir ingen interessekonflikter.
Mona Kristiansen Beyer (f. 1956) er spesialist i radiologi og overlege.

Forfatter har fylt ut ICMJE-skjemaet og oppgir ingen interessekonflikter

Espen Dietrichs (f. 1956) er spesialist i nevrologi, avdelingssjef ved Nevrologisk avdeling. Oslo universitetssykehus, og professor ved Det medisinske fakultet, Universitetet i Oslo. Forfatter har fylt ut ICMJE-skjemaet og oppgir følgende interessekonflikter: Han har mottatt forelesningshonorar fra Medtronic.

Mona Skjelland (f. 1956) er spesialist i nevrologi og overlege.

Forfatter har fylt ut ICMJE-skjemaet og oppgir ingen interessekonflikter.

\section{Litteratur}

1. Louis ED, Ottman R, Hauser WA. How common is the most common adult movement disorder? estimates of the prevalence of essential tremor throughout the world. Mov Disord 1998; 13: 5-10. 2. Toft M, Lilleeng B, Ramm-Pettersen J et al. Behandling av bevegelsesforstyrrelser med dyp hjernestimulering. Tidsskr Nor Legeforen 2008 : 128: 1972-6.

Mottatt 21.3. 2014, første revisjon innsendt 28.5. 2014, godkjent 5.6. 2014. Redaktør: Hanne Støre Valeur.

Engelsk oversettelse på www.tidsskriftet.no

Video på www.tidsskriftet.no 